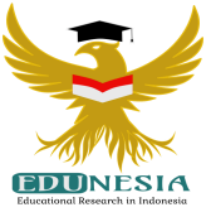

\title{
Literacy as an Effective Media for Distance Learning
}

\author{
Sinta Diana; Selvie Sianipar2; ${ }^{2}$ Riodinar Harianja ${ }^{3}$ \\ 1,2Machine Maintenance, Politeknik Bina Mandiri Prestasi, Indonesia \\ ${ }^{3}$ Accountant, Politeknik Bina Mandiri Prestasi, Indonesia \\ ${ }^{1}$ Corresponding Email: sintadianamartaulina@gmail.com, Phone Number : 0813 xxxx xxxx
}

\author{
Article History: \\ Received: May 11, 2021 \\ Revised: Jun 21, 2021 \\ Accepted: Jun 24, 2021 \\ Online First: Jun 30, 2021
}

\section{Keywords:}

Distance Learning,

Literacy, Media.

\section{Kata Kunci:}

Literasi,

Media,

Pembelajaran jarak jauh

\section{How to cite:}

Diana, S., Sianipar, S., \& Harianja, R. (2021). Literacy as an Effective Media for Distance Learning. Edunesia: Jurnal Ilmiah Pendidikan, 2 (3): 591-599.

This is an open access article under the $C C-B Y-N C$-ND license (c) (1) $\odot$

\begin{abstract}
The emergence of the phenomenon of distance learning as online learning during the pandemic is concerned about the quality of achieving learning objectives. Finally, distance learning becomes an option so that the implementation of higher education can still be carried out like conventional learning. This restlessness opens opportunities for literacy methods as an effective medium in distance learning. The purpose of this research is to explain that literacy is not limited to reading and writing skills. Familiarize students with reading and accessing information before learning is a positive habit for organizing the brain and critical analysis skills. The research method used in research during this pandemic is a literature study with a qualitative approach. The type of data used is secondary data obtained from various sources such as books, journals, scientific writings as well as observations of online learning at the research campus. The research findings refer to several references, that literacy is the local wisdom of the Indonesian people, has practical goals that can be utilized and developed as a renewal in the era of educational technology. Thus, during this pandemic, literacy has been developed in various aspects of learning life such as technology, culture, politics, finance, information, and so on. The impact of literacy effectively has made students able to study independently and learn actively. Mastery of technology in literacy creates student learners, thinkers, researchers, and agents of change. The use of literacy as a medium for distance learning is an opportunity that this learning provides an opportunity for anyone to learn. The effectiveness of literacy as a medium in distance learning is very important to be developed with the mastery of digital technology.
\end{abstract}

Abstrak: Munculnya fenomena pembelajaran jarak jauh sebagai pembelajaran dalam jaringan di masa pendemi mengkhawatirkan mutu dalam mencapai tujuan pembelajaran. Akhirnya pembelajaran jarak jauh menjadi pilihan agar pelaksanaan pendidikan tinggi tetap dapat dilakukan seperti pembelajaran konvensional. Keresahan ini membuka peluang metode literasi sebagai media efektif dalam pembelajaran jarak jauh. Tujuan penelitian ini adalah memaparkan bahwa literasi bukan sebatas keterampilan membaca dan menulis. Membiasakan mahasiswa membaca dan mengakses informasi sebelum pembelajaran merupakan pembiasaan yang positif untuk mengorganisasikan otak dan kemampuan menganalisis yang kritis. Metode penelitian yang digunakan dalam penelitian di masa pandemi ini adalah studi literatur "library research" (penelitian pustaka) dengan pendekatan kualitatif. Jenis data yang digunakan adalah data sekunder yang diperoleh dari berbagai sumber seperti buku, jurnal, tulisan ilmiahserta pengamatan pembelajaran dalam jaringan di kampus peneliti. Temuan penelitian merujuk kepada beberapa referensi, bahwa literasi merupakan kearifan lokal bangsa Indonesia, mempunyai tujuan-tujuan praktis yang dapat dimanfaatkan dan dikembangkan sebagai pembaharuan di era teknologi pendidikan. Maka, di masa pandemi ini literasi telah dikembangkan di berbagai aspek kehidupan pembelajaran seperti teknologi, budaya, politik, keuangan, informasi, dan sebagainya. Dampak literasi secara efektif telah menjadikan mahasiswa mampu belajar mandiri dan belajar aktif. Penguasaan teknologi dalam literasi menciptakan mahasiswa pembelajar, pemikir, peneliti, dan pelaku perubahan. Pemanfaatan literasi sebagai media pembelajaran jarak jauh merupakan peluang bahwa pembelajaran ini memberikan kesempatan kepada siapa pun untuk belajar. Efektivitas literasi sebagai media dalam pembelajaran jarak jauh sangat penting dikembangkan dengan penguasan teknologi digital. 


\section{A. Introduction}

Literacy is an ancestral heritage that has been used to convey information orally and in writing. This information was passed down orally through customs which in the end became a virtuous and strong science, whose acceptance has been acknowledged to this day, its feasibility is still being carried out. This ongoing acceptance is an appreciation of the next generation in preserving culture by word of mouth. In writing, the findings of artifacts, inscriptions and writings on palm leaves are historical facts that cannot be denied or denied. This description shows that before modern civilization and digitalization, time has been a silent witness that literacy can be used as a medium in various aspects of life. One of them is the world of education (Warsihna, 2016).

In the era of information systems, literacy has a big role in storing and accessing information as a data bank. The pandemic period has changed everything, paralyzing the national and international economy. However, the Covid-19 pandemic has opened our eyes to not always rely on real numbers. Through the covid-19 epidemic, it has changed the world to open its eyes. We can download or upload information in lessons held this year online. Limitations in doing learning in the classroom have been transferred online through literacy. In the Indonesian Dictionary the word "literacy" has 3 meanings, firstly the ability to write and read, secondly knowledge or skills in certain fields or activities (eg computers), and thirdly the ability of individuals to process information (Kivunja, 2015; Lordache et al, 2017). Linguistically, literacy namely the ability to write and read. In English, literacy means competence or knowledge in a particular field. The opposite is illiteracy, which in Indonesian is known as illiterate or unable to read. Literacy comes from the Latin, literatus, which means "learned person".

he National Institute for Literacy (NIFL) states, "Literacy is an individual's ability to read, write, speak, calculate and solve problems at the skill level required in work, family and society. According to UNESCO, people's understanding of the meaning of literacy is strongly influenced by academic research, institutions, national contexts, cultural values, and experiences. The most common understanding of literacy is a set of tangible skills, particularly the cognitive skills of reading and writing, which are independent of the context in which they were acquired and from whom they were acquired. literacy is the right of everyone and is the basis for lifelong learning. Literacy abilities can empower and improve the quality of individuals, families, and communities (Batterham et al, 2016). From the two understandings of literacy quoted as above, it can be emphasized that literacy is an ability which can improve the quality of individuals, families and communities through reading knowledge and writing competence. So, literacy is not only synonymous with reading and writing culture, but also media literacy, cultural literacy, technological literacy, financial literacy, and so on. In essence, every individual in society can be literate as a capital to become an advanced, modern, and civilized human being. Various studies refer that the literacy movement is very massive to catch up with other more advanced nations. The literacy movement in the world of education from elementary to college reading habits can be carried out before learning begins to become a routine that builds information. This literacy activity should be supported and carried out by teachers and lecturers in their respective educational environments. 


\section{B. Method}

This research was conducted in online classes at the research campus, the research subjects were online classes that have been in effect since April 2020 (Even Semester/Semester B) totaling 299 students from Study Programs: Accounting, Banking, English, Nursing and Engine Repair and Hotel Management. The object of the research is literacy as an effective medium in distance learning. Literacy as a learning medium in online classes is expected to be proactive in dealing with learning during the pandemic. Primary data in this study was obtained from the role of lecturers, students, and parents through a questionnaire. Considering the pandemic situation, secondary data is also used as a comparison, which is taken and accessed from the literature of books, articles, journals and learning observations on campus through e-learning. This secondary data is a support in this study to take a closer look at the literacy approach that has been used in distance learning. Then the secondary data is compared with the learning in the campus environment of the researcher. After that, the findings in the field are classified with several previous and relevant studies. The next step is to analyze several cases similar to learning observations in the campus network of researchers to see if their learning outcomes have HOTS (Higher Order Thinking Skills), abilities that do not just recall, restate or refer without processing (Lai, 2011). Through research, it is hoped that literacy will be able to be an effective medium in transferring, thinking critically and solving problems.

\section{Result and Discussion}

\section{Literacy Goals}

As explained above, literacy is an activity to cultivate reading and writing movements for individuals, families and communities, especially the world of education. This activity movement accustoms each individual to absorb information through reading and then summarize it in writing skills. Thus, the potential of each individual can be developed his language skills as a skill. Language skills are not only listening, reading, speaking to writing but also the ability to access information and literacy. The purpose of empowering literate individuals is as follows.

1. Cultivate and develop good character.

2. Cultivate and develop a literacy culture in schools and communities.

3. Can increase the knowledge possessed by reading all kinds of useful information.

4. Can also improve one's understanding in taking the essence of a reading.

5. Filling time with literacy to be more useful.

6. Give a critical assessment of someone's writing.

7. Strengthening personality values by reading and writing.

The seven literacy goals above in general are to create and develop good character.

\section{Cultivate and develop good character}

There are several important things to note that literacy fosters and develops good character. First, his curiosity can be obtained from books and other sources (asking questions, discussing with other people, who are considered to be able to provide answers). As an individual who wants to know everything, he will not be ashamed to ask questions and always thirst for knowledge to fulfill his desire for knowledge. Second, mentally want to move forward, people who want to always know, he will diligently read and seek all information such as his curiosity about how entrepreneurs, hard workers, politicians, whose 
success is achieved by their life experiences which he reads are the motivation for his life. Third, critical and analytical thinking, People who like to read will have critical thinking skills compared to people who rarely read. The ability of people who are accustomed to reading, their analytical skills are honed. Every word and sentence he reads, the impetus to keep thinking in analyzing something. Reading activity has made his brain continue to work and create new thoughts. Fourth, the desire to share, after reading books or accessing information, of course someone will gain knowledge and it will be more useful if he can share with others. Knowledge that is shared with others will increase the benefits and blessings. There is a value of worship and satisfaction when you can share knowledge with others. Fifth, discipline, people who are accustomed to reading books or accessing information will be disciplined in managing their time to make time to be literate. He always does this because reading is a necessity that must be fulfilled. The habit of reading makes him have to have time as a target so that his reading needs can be completed by maximizing his limited time. By getting used to reading, they usually have a regular lifestyle. Sixth, hard work, people who have the habit of reading usually need hard work to do it in between their busy lives to share time between work and reading activities. Reading can be done through fast reading or slow reading or reading sheet by sheet, even repeated so that the topic being read can be understood. Seventh, being grateful, reading activities as a habitual activity are an expression of gratitude to God Almighty because they are still given the opportunity to practice understanding skills, learning opportunities as well as useful and dignified time fillers (Nanda et al, 2018). Reading activities are able to form individuals and communities who are thirsty for knowledge to create human learners, human thinkers, human researchers, and human bearers of renewal.

\section{Cultivate and develop a literacy culture on campus and in the community}

Literacy culture in the realm of students plays an important role in the survival of students in their education. His educational achievements enable students to express knowledge and research empirically and experimentally in a scientific paper. Therefore, all learning must be supported by reading. Reading and listening are parts of language skills that are receptive, appreciative, and functional. Both are processes of changing form into meaning. The difference is, in listening, the symbol changes in the form of sound, while in reading the symbol changes in the form of writing. Writing activities are preceded by reading activities as a continuous language skill. In other words, the campus as a means of formal education involving, lecturers, students, libraries, and internet access is an effort to build literacy activities (Arnold-Garza, 2014).

\section{Can increase the knowledge possessed by reading all kinds of useful information}

Reading is a literacy movement to increase one's knowledge. Reading is an important thing in all kinds of learning processes. Through reading, various scientific activities lead a person to success. Reading activities that always start learning before starting learning foster student interest in acquiring knowledge in a fun way. Thus, students are able to learn independently and learn creatively with a lecturer facilitator who guides them as a reference and discusses it again to explore, find, formulate a discussion. The literacy movement has been reactivated to shorten the learning gap in the network, which often haunts the community's bad image about the quality of learning. Online learning during a pandemic is considered to be constrained by distance and physical encounters. 
However, through the literacy movement in utilizing the internet network, lecturers as facilitators have educated students to be able to learn independently and be able to learn creatively. The role of literacy through reading movements has spurred his curiosity to access more accurate information to refer to the target of achieving learning goals.

\section{Can also improve one's understanding in taking the essence of a reading.}

Research shows that the higher a person's reading literacy, the higher the reading comprehension. Vice versa, the lower a person's reading literacy, the lower that person's reading comprehension. So, if you want high reading comprehension, students' reading literacy must be improved

\section{Filling time with literacy to be more useful}

Applying literacy as a habit and necessity in life makes the world of campus education more alive. Learning that begins with literacy results in students being able to learn independently in managing their study time. Independent learning means that students seek, explore, find, differentiate and formulate something with the assistance of lecturers. Lecturers, learning classes and support for library facilities and campus e-learning are able to make students active and creative so as to produce an innovation. The innovation is not limited to physical form, however, scientific designs as hypotheses are proven so that they become a novelty in learning outcomes.

\section{Give a critical assessment of someone's writing}

As explained above, high student literacy skills greatly affect the acquisition of various information related to the business of living life (competence), the meaning of literacy that continues to grow requires students to be diligent in accessing information or information literacy (Maddison, 2013). The ability of students in literacy makes a generation that is more prepared and able to face future challenges by mastering literacy. By increasing literacy mastery, his skills in critical thinking also increase. One of the life skills that need to be developed is the thought process as outlined in scientific writing, which organizes the brain and analytical skills.

\section{Strengthen personality values by reading and writing}

In overcoming the phenomenon of disinformation, literacy skills are needed among students. Literacy is not just the ability to read and write, but literacy means literacy in technology, politics, critical thinking, and being sensitive to the surrounding environment (Brit et al, 2014). The importance of literacy awareness greatly supports one's success in dealing with various problems. If a student has literacy skills, he will gain knowledge and document a piece of his experience as a reference in the future.

\section{Literacy Benefits}

Based on the literacy objectives, the benefits obtained include,

1. Increase vocabulary.

2. Optimizing brain work.

3. Adding new insights and information.

4. Improve interpersonal skills. 
5. Sharpen yourself in capturing the meaning of an information that is being read.

6. Develop verbal skills.

7. Train the ability to think and analyze.

8. Improves one's focus and concentration.

9. Train in writing and also stringing meaningful.

In general, the purpose of literacy is to create and develop good character. So, it is very unfortunate that the local wisdom built by the previous ancestors was not cultivated in building human beings who are adaptive, creative and responsive to changing times. Literacy inheritance means mastery of literacy as an important indicator to improve the achievements of the younger generation to achieve success. Planting literacy and culture as early as possible must be realized as the main capital for the realization of an intelligent and cultured nation. An intelligent and cultured nation is a nation that is rich in knowledge and is able to manage its intelligence to build its nation and state. This is the answer why we must be literate.

\section{Learning Media}

Media is a tool or means such as newspapers, radio, magazines, television, films, posters, and banners (Wiraseptya, 2019). Thus the media is a tool or means as an intermediary to deliver learning materials. This is because learning activities must have objectives, materials, methods, media (tools), and evaluations. Elements of methods and media (tools) are elements that cannot be separated from other elements that function as a way or technique to deliver learning materials to reach their goals. Utilization of relevant media can optimize learning (Wu et al, 2013).

\section{Benefits of Learning Media}

The benefits of learning media can be detailed as follows.

1. Submission of subject matter can be uniformed.

2. The learning process becomes clearer and more interesting.

3. The learning process becomes more interactive.

4. Efficiency in time and energy.

5. Improving the quality and learning outcomes of students/students.

6. Media allows the learning process to be carried out anywhere and anytime.

7. Media can foster a positive attitude of students towards the material and the learning process.

8. Changing the role of lecturers/teachers in a more creative and positive direction.

\section{Literacy as a Learning Media}

Literacy is a process of learning to read and write that requires high encouragement and motivation. Weak interest in reading among students and students can hinder the absorption and acquisition of information in the learning process. Therefore, literacy in learning to all citizens of the education world must be motivated so that lecturers/teachers as well as students and students can be creative in utilizing literacy as a learning medium. Literacy as a medium is not just a routine as a learning ritual, but must continue to be 
encouraged to be adaptive, creative in order to be able to run a higher quality learning process.

\section{Distance Learning}

Distance learning is also known as open system learning because it provides an opportunity for anyone to learn. The rules and regulations of learning are very dynamic, not as rigid as conventional learning such as face-to-face in class. Distance learning is learning that prioritizes independence. Lecturers/teachers can provide learning materials without having to meet face-to-face in a different room. This kind of learning can be done at the same time or at different times. Distance Learning is learning using a medium that allows reactions between teachers and students in different places and even at different distances. In the learning process so that PJJ can be carried out well, there are several important things that must be considered. For example, attention, teacher confidence, being able to use technology creatively so as to allow good interaction with learners (students/students).

Some of the conveniences/advantages in implementing distance learning are the distribution of learning throughout the place without any capacity limit because it does not use the classroom as a learning space. Second, Distance Learning is not limited by time so that it can be carried out with the availability of each time, which does not interfere with other activities. Third, students can choose topics or learning materials according to their individual needs and desires. This is very good to support the achievement of learning objectives. Fourth, the length of learning depends on the ability of each learner. Fifth, learning materials can be updated in accordance with the development of information technology stored in digital form. Sixth, Distance Learning can be carried out interactively so that it attracts the attention of students, students and students.

\section{Literacy as a Distance Learning Media}

Literacy is an ability that can improve the quality of individuals, families and communities through reading knowledge and writing competence. However, in this digital era, literacy is no longer limited to the ability to read and write conventionally. Literacy in changing times by situations and conditions has allowed Distance Learning to be one of the best considerations in achieving learning goals. The learning objectives that have been taking place face to face in the classroom can be replaced by Distance Learning.

Various kinds of literacy can be adapted to the needs of each learning. One variety of literacy is digital literacy which has become part of Distance Learning activities. Especially when the pandemic is still ongoing today, learning is focused on Work from Home (WFH). Thus, literacy cultivation is a solution that must be promoted and supported as a learning medium. Along with technological advances, teachers and students must improve their competence in the digital era through literacy as a learning medium. The ability and mastery of technology helps the literacy process in the delivery of the learning process. Although the distance learning process with literacy is still not optimal due to the lack of digital knowledge of individuals, families, and communities.

\section{Conclusion}

From the descriptions above, it can be concluded that literacy as a competency that can improve the quality of learning, especially distance learning is a learning medium that must be continuously activated to achieve learning objectives. Learning objectives are no 
longer just meeting curriculum standards. Literacy as a distance learning medium also raises the spirit of caring for the abilities and interests of individuals, families and communities to promote literacy in all aspects. Literacy has opened the limitations of distance learning regardless of the limitations of space and time. Literacy has become a learning medium that can help accelerate learning objectives. Literacy is no longer limited to reading and writing. Literacy is also directed to science, technology, politics, culture, information, finance, and various other literacys. The role of literacy as a learning medium during a pandemic is a very simple learning medium that can be relied on through technology.

Experience from various developed countries, research shows that there has been a renewal in the world of education to respond to literacy through technology. The world of education as a means of educating the nation's children in creating the younger generation on campus must be reliable in literacy. Distance learning does not dampen learning outcomes that can be carried out optimally. The challenges of online learning during the pandemic have diverted our attention from just reading books and receiving learning materials from lecturers. However, through literacy as an effective learning medium, it has enabled students to learn independently and learn actively with mastery of technology. The limitation of physical meetings in the classroom is no longer an ideal learning requirement. Literacy as a distance learning medium has been able to bridge the problem of learning in the network through a system prepared in campus e-learning. All of this is done through mastery of literacy which has become the wisdom of our ancestors before there was knowledge of reading and writing. Now, literacy as a distance learning media can be accessed through the mastery of technology. So, it can be underlined that literacy is an effective medium in distance learning.

\section{References}

Arnold-Garza, S. (2014). The flipped classroom teaching model and its use for information literacy instruction. Communications in Information Literacy, 8(1), 9.

Batterham, R. W., Hawkins, M., Collins, P. A., Buchbinder, R., \& Osborne, R. H. (2016). Health literacy: applying current concepts to improve health services and reduce health inequalities. Public health, 132, 3-12.

Britt, M. A., Richter, T., \& Rouet, J. F. (2014). Scientific literacy: The role of goal-directed reading and evaluation in understanding scientific information. Educational Psychologist, 49(2), 104-122.

Iordache, C., Mariën, I., \& Baelden, D. (2017). Developing digital skills and competences: A quick-scan analysis of 13 digital literacy models. Italian Journal of Sociology of Education, 9(1).

Kivunja, C. (2015). Exploring the Pedagogical Meaning and Implications of the 4Cs" Super Skills" for the 21st Century through Bruner's 5E Lenses of Knowledge Construction to Improve Pedagogies of the New Learning Paradigm. Creative Education.

Lai, E. R. (2011). Critical thinking: A literature review. Pearson's Research Reports, 6, 40-41. 
Maddison, T. (2013). Learn where you live: delivering information literacy instruction in a distributed learning environment. Journal of library $\mathcal{E}$ information services in distance learning, 7(3), 264-277.

Nanda, S. R., Abdul, N. B., \& Daddi, H. (2018). The Use Of Quizizz Application In Improving Students' Reading Comprehension Skill At SMKN 3 Takalar. An Experimental Research, 1(2).

Warsihna, J. (2016). Meningkatkan literasi membaca dan menulis dengan teknologi informasi dan komunikasi (TIK). Jurnal Kwangsan, 4(2), 67-80.

Wiraseptya, T., Imani, R., Afdhal, M., \& Yanto, H. (2019, December). Interactive Map Model of Flat Design for Istano Basa Pagaruyung Tourism Development. In Journal of Physics: Conference Series (Vol. 1339, No. 1, p. 012034). IOP Publishing.

Wu, F., Lu, X., Zhang, Z., Yan, S., Rui, Y., \& Zhuang, Y. (2013, October). Cross-media semantic representation via bi-directional learning to rank. In Proceedings of the 21st ACM international conference on Multimedia (pp. 877-886). 